\title{
Approaches to the Teaching of English Literature Preferred by Students in Selected Malaysian Secondary Schools
}

\author{
Engku Suhaimi Engku Atek, Isyaku Hasan, \\ Mohd Nazri Latif Azmi, Mohd Hazli Yah \\ and Nor Jijiana Azmi* \\ Universiti Sultan Zainal Abidin (UniSZA) \\ Terengganu, Malaysia
}

Received 24.09.2020, received in revised form 12.01.2021, accepted 12.03.2021

\begin{abstract}
In 2000, the English literature component was incorporated into the English language syllabus in Malaysian secondary schools. This program still attracts interesting discourse amongst researchers, educators, and policymakers. Determining an appropriate approach to the teaching of English literature is crucial in achieving positive literature learning outcomes. Therefore, this study aims to identify the most preferred approaches to the teaching of English literature in selected secondary schools in Terengganu, Malaysia. The study employed a descriptive survey method in which structured questionnaire was used as a data-gathering instrument. The data were gathered from a sample of 403 students across four different public secondary schools in Terengganu: SMK Kompleks Seberang Takir, SM Sains Sultan Mahmud, SMKA Dato Haji Abbas, and SMK Kompleks Gong Badak. The data were analyzed using descriptive statistics via the SPSS statistical software package (SPSS Inc., Chicago, IL, USA, 20.0). The study found that the moralphilosophical approach to the teaching of English literature is the most preferred approach amongst the students, followed by the information-based approach and the languagebased approach. This shows that teachers of English literature incorporate moral values in their lessons. It is envisaged that the findings of this study could be especially useful in the process of curriculum development, particularly in the Malaysian context. Besides, this study could raise teachers' awareness of their students' preferences for literature teaching approaches.
\end{abstract}

Keywords: Teaching approach, classroom, literature, Malaysia, second language.

Research area: pedagogy.

Citation: Engku Suhaimi Engku Atek, Isyaku Hasan, Mohd Nazri Latif Azmi, Mohd Hazli Yah, Nor Jijiana Azmi (2021). Approaches to the teaching of English literature preferred by students

(C) Siberian Federal University. All rights reserved

* Corresponding author E-mail address: esuhaimi@unisza.edu.my, isyaku87@gmail.com,mohdnazri@unisza.edu.my, jijidianaazmi@unisza.edu.my

ORCID: 0000-0002-4889-2904 (Engku Suhaimi Engku Atek); 0000-0002-8260-2894 (Isyaku Hasan); 0000-0002-47125332 (Mohd Nazri Latif Azmi); 0000-0003-3984-780X (Mohd Hazli Yah); 0000-0001-7922-7993 (Nor Jijiana Azmi) 
in selected Malaysian secondary schools. J. Sib. Fed. Univ. Humanit. Soc. Sci., 14(3), 396-407. DOI: $10.17516 / 1997-1370-0729$.

\title{
Подходы к преподаванию английской литературы, предпочитаемые учениками некоторых малазийских средних школ
}

\author{
Энгку Сухайми Энгку Атек, Исяку Хасан, \\ Мохд Назри Латифф Азми, Мохд Хазли Да, \\ Нор Джиджиана Азми \\ Университет Султана Зейнала Абидина \\ Малайзия, Теренггану
}

\begin{abstract}
Аннотация. В 2000 г. изучение английской литературы было включено в программу обучения английскому языку в средних школах Малайзии. Эта программа попрежнему обсуждается исследователями, преподавателями и политиками. Определение подходов к преподаванию английской литературы имеет решающее значение для повышения качества обучения. Данное исследование направлено на определение наиболее предпочтительных подходов к преподаванию английской литературы в отдельных средних школах Теренггану, Малайзия. В исследовании использовался метод опроса: структурированный опросник был выбран в качестве инструмента для сбора данных. Выборка представлена 403 учащимися из четырех государственных средних школ в Теренггану (SMK Kompleks Seberang Takir, SM Sains Sultan Mahmud, SMKA Dato Haji Abbas и SMK Kompleks Gong Badak). Анализ данных осуществлялся методами описательной статистики с помощью пакета программ SPSS (SPSS Inc., Чикаго, Иллинойс, США, 20.0). Исследование показало, что для большинства студентов важным является морально-философский подход к преподаванию английской литературы, на втором месте обучающиеся выделяют информационный и языковые подходы. Опрос показывает, что учителя английской литературы включают в свои уроки изучение моральных ценностей. Предполагается, что результаты этого исследования могут быть особенно полезны в процессе разработки учебных программ и представляют особый интерес для Малайзии. Кроме того, это исследование может повысить осведомленность учителей о предпочтениях учащихся в отношении методов преподавания литературы.
\end{abstract}

Ключевые слова: обучающий подход, школьный класс, литература, Малайзия, второй язык.

Научная специальность: 13.00.00 - педагогические науки.

\section{Introduction}

The importance of literature teaching approaches has drawn increasing attention especially in the field of second language learning (Amer, 2003; Tina et al., 2007; Ghazali et al.,
2009; Rashid, Vethamani, \& Rahman, 2010; Khatib, Derakhshan, \& Rezaei, 2011a; Mustakim, Mustapha, \& Lebar, 2014; Krishnasamy, 2015). Research has highlighted the importance of literature teaching approaches in the process 
of knowledge acquisition and achieving positive learning outcomes (Timucin, 2001; Savvidou, 2004; Bridget \& Omar, 2007; Divsar \& Tahriri, 2009). In 2000, the literature component was incorporated into the English syllabus in Malaysian secondary schools (Ghazali et al., 2009). Until today, this literature component program attracts the attention of researchers, teachers, and policymakers. To this end, researchers and teachers are searching for better strategies for teaching English literature courses (Bridget \& Omar, 2007; Hwang \& Embi, 2007; Ahmad \& Aziz, 2009; Krishnasamy, 2015). Therefore, determining an appropriate approach to the teaching of English literature is imperative (Divsar \& Tahriri, 2009; Krishnasamy, 2015).

English literature is recognized as an effective means of language learning (Simpson, 2003; Hişmanoğlu, 2005; Paran, 2008; Keshavarzi, 2012). Besides, learning of English literature shapes the learners' personality and self-awareness through communication with the literary texts. It advances their enthusiasm and comprehension of the world around them (Cheng, 2016). Therefore, English literature could serve as an excellent choice to support nationalism. English literature plays an educational, recreational, moral, cultural, and sociopolitical role in the learning environment (Ihejirika, 2014; Azmi et al., 2020). In Malaysia, the literature component in the language syllabus of secondary schools aims to develop affection for literature in the students and equip them with an in-depth understanding of English literature (Subramaniam, 2007). The syllabus incorporates various literary texts including short stories, novels, poems, and drama. In this regard, the Ministry of Education specified that the students should have the ability to critically evaluate the characters, setting, plot, as well as the author's viewpoint and other artistic components in literary texts.

Very few studies investigated the approaches to the teaching of English literature in the Malaysian context (Bridget \& Omar, 2007; Hwang \& Embi, 2007; Rashid et al., 2010; Mustakim et al., 2014; Krishnasamy, 2015), focusing on approaches preferred and employed by teachers. None of these studies specifically considered the students' preferences for approaches to the teaching of English literature. Therefore, this study aims to identify the most preferred approaches to the teaching of English literature in selected secondary schools in Terengganu, Malaysia. Since teacher-centered approaches may result in less engagement with students in the learning process (Bridget \& Omar, 2007; Gopala et al., 2012), focusing on the learner's perspective could be much imperative. Learner's enthusiasm and comprehension are likely to be improved by applying an appropriate teaching approach (Timucin, 2001; Rashid et al., 2010). The findings of this study are expected to advance our understanding of the current situation with regard to teaching and learning of English Literature.

\section{Literature Review}

A number of studies were conducted to investigate the literature teaching approaches in ESL classroom (Bridget \& Omar, 2007; Tina et al., 2007; Ghazali et al., 2009; Divsar \& Tahriri, 2009; Rashid et al., 2010; Mustakim et al., 2014). Most of these studies demonstrated an increasing awareness of the importance of using appropriate approaches to the teaching of English literature (Amer, 2003; Khatib et al., 2011a). For example, Rashid et al. (2010) identified the approaches and strategies employed by teachers in teaching the literature component to less proficient students in Malaysia. The study found that the information-based approach is popularly employed by teachers, followed by the moral-philosophical approach and paraphrastic approach. The findings indicate that the teaching approach is influenced by the students' inability to comprehend the English language. In this regard, Hwang and Embi (2007) noted that teaching approaches are largely influenced by students' language proficiency and attitudes.

Similar to the findings of Rashid et al. (2010), Bridget and Omar (2007) found that the moral-philosophical approach was the most preferred approach amongst teachers of English literature. However, Krishnasamy (2015) found that teachers applied the overall approaches of teaching literature at an average level. Besides, Ahmad and Aziz (2009) found that students 
admit their teachers have a positive attitude towards literature and literature teaching, and the literature component class has also given a great impact on the students. Nevertheless, Tina et al. (2007) found that many teachers claimed that the language level of the literary texts selected by the Ministry was difficult for many students to comprehend. With limited vocabulary and lack of competence in language skills, the literature component became a challenge for many students. As a result, teachers may face great difficulties in teaching literature to less proficient students. Therefore, they have to adopt various approaches to suit the needs of this group of students to achieve the objectives of the literature component.

In addition, Hwang and Embi (2007) examined the approaches employed by teachers in teaching the literature component in selected Malaysian secondary schools. The study showed that the paraphrastic approach is popularly used by teachers, followed by the information-based approach and moralphilosophical approach. In the same vein, Mustakim et al. (2014) identified the approaches employed by teachers in teaching Contemporary Children's Literature (CCL) program to upper primary school. The study found that the information-based approach and paraphrastic approach were the most favored approaches by teachers in the teaching of CCL programs. Ghazali et al. (2009) also explored the teaching strategies and the students' attitudes towards the literature texts used in Malaysian secondary schools. The study found that students have positive attitudes towards the text selection although they were less enthusiastic about the teaching methods used by teachers.

Furthermore, Savvidou (2004) examined various approaches and provides a rationale for an integrated approach to teaching literature in the language classroom. According to the study, an integrated approach to the teaching of literature in the language classroom offers students the opportunity to develop linguistic and communicative skills. Similarly, Timucin (2001) investigated the responses of undergraduate students to a proposed literature teaching approach in Turkey. The study used an integrated approach comprising language-based ap- proaches and pedagogical stylistics. According to the study, the proposed teaching approach significantly enhances the level of students' involvement in the literature learning process. Likewise, Divsar and Tahriri (2009) proposed an integrated model based on three models for teaching literature: Language-based, contentcultural model, and personal- model. The study confirmed the effectiveness of using a multistep approach to teaching literature.

English literature provides an interesting drive for language teaching and learning due to its outstanding features (Khatib, Rezaei, \& Derakhshan, 2011b). The teaching of English literature develops the students' language skills and cultural awareness, as well as encourages their critical thinking (Van, 2009; Mahzan, Alias, \& Ismail, 2020; Azmi, Hassan, \& Sidek, 2020). In this regard, teachers play a significant role in the students' knowledge acquisition process. Therefore, it is important to ensure that teachers are equipped with enough pedagogical content knowledge for classroom practices, which in turn affect the students' learning outcomes and achievement (Ghazali et al., 2009). On the other hand, students' attitude is one of the major determinants of their success in language learning (Candlin \& Mercer, 2001). Students' involvement in the teaching-learning process is paramount, and their positive contributions could result in methodological success (Ahmad \& Aziz, 2009).

In sum, previous studies on literature teaching approaches confirmed that teaching approaches are largely influenced by students' language proficiency, and an integrated approach to the teaching of English literature offers great opportunity to develop language proficiency and enhance the level of students' involvement in the learning process. The previous studies focused on the approaches and strategies employed by teachers (Bridget \& Omar, 2007; Hwang \& Embi, 2007; Rashid et al., 2010; Mustakim et al., 2014; Krishnasamy, 2015), teachers' attitudes toward literature teaching (Ahmad \& Aziz, 2009), teaching strategies (Ghazali et al., 2009), and integrated approaches to literature teaching (Timucin, 2001; Savvidou, 2004; Divsar \& Tahriri). Therefore, the present study focuses on stu- 
dents' preferences for approaches to teaching of English literature in Malaysia.

\section{Literature Teaching Approaches in ESL Classroom}

Acceding to Carter and Long (1991), there are three models of teaching literature: 1) the cultural model, which requires learners to explore and interpret the social, political, literary and historical context of a specific text;2) the language model, which enables learners to access a text in a systematic and methodical way in order to exemplify specific linguistic features such as literal and figurative language, direct and indirect speech; 3) the personal growth model, which focuses on the particular use of language in a text, as well as placing it in a specific cultural context (Carter \& Long, 1991; Rashid et al., 2010; Mustakim et al., 2014). These three models of teaching literature have been integrated in the following approaches.

1. Information-based approach: As the name implies, this approach represents a way of teaching knowledge about literature where literature is seen as a means of offering a source of information to learners (Carter, 1986; Hwang \& Embi, 2007; Rashid et al., 2010).

2. Paraphrastic approach: This approach enables teachers to use simpler words and sentence structures compared to the complicated ones in the literary texts. At times, the teacher may paraphrase or translate complicated words and sentences into local languages (Hwang \& Embi, 2007; Rashid et al., 2010). Therefore, this approach deals with the surface meaning of the texts.

3. Stylistic approach: This approach guides learners toward a closer comprehension of the literary texts via linguistic analysis and literary appreciation. There are two objectives of this approach. Hence, this approach enables learners to make meaningful interpretations of the texts and expand their awareness and knowledge of the language (Lazar, 1993; Hwang, \& Embi, 2007).

4. Language-based approach: This represents an approach where literary texts are viewed as a means of helping learners to develop language skills or proficiency. In this approach, learners are exposed to the target language and connected to certain aspects of the language such as vocabulary (Carter, 1986; Hwang \& Embi, 2007; Rashid et al., 2010).

5. Personal-response approach: This approach focuses on the learner's response to the literary text. It enables learners to respond to the author's intentions and the meanings evident in the text based on their understanding and thought. This approach motivates learners to read by making a connection between the themes studied from the texts and their individual life experiences (Carter, 1986; Rashid et al., 2010).

6. Moral-philosophical approach: As the name implies, this approach enables teachers to incorporate moral values in their lessons (Carter \& Long, 1991; Rashid et al., 2010; Mustakim et al., 2014). It focuses on discovering moral values while reading the literary text (Rashid et al., 2010).

An approach refers to «the basic philosophy or belief concerning the subject matter being considered» (Hofler, 2010: 71). For a successful literature program, teachers must be acquainted with a variety of approaches, techniques, and activities to encourage and develop learners' interest and knowledge of literature (Whitehead, 1968). Therefore, an appropriate teaching approach could have a positive influence on the teaching and learning process (Timucin, 2001; Rashid et al., 2010). Based on the review of previous studies and the approaches to the teaching of literature, this study aims to identify the most preferred approaches to the teaching of literature amongst students in the selected secondary schools.

\section{Method}

This study employed a quantitative approach in which descriptive survey method was used. Survey designs generalize results from a sample to a population and therefore allow for strong and valid conclusions (Allen, Titsworth, \& Hunt, 2009; Creswell, 2012). Besides, surveys provide useful information to describe trends about a large number of people (Creswell, 2012). Therefore, a questionnaire was used in this study due to its ability to gather easily quantified data within a short possible time. It is usually considered as an objective 
research instrument that can produce generalizable results (James, 2012).

\section{Data Collection}

This study was limited to English language students selected from four different public secondary schools in the State of Terengganu, Malaysia: SMK Kompleks Seberang Takir, SM Sains Sultan Mahmud, SMKA Dato Haji Abbas, and SMK Kompleks Gong Badak. The literature component is incorporated into the English language syllabus offered from Form One until Form Five. The target population of this study consists of Form Four students in the selected schools, which suggests that the students have been learning English literature for more than three years. Thus, this group of students could be considered a good sample as they can share their experiences regarding the approaches employed by their teachers in teaching English literature. Simple random sampling was used to select a sample of 420 from the students. Random sampling refers to the method of sample selection which gives each element in the population an equal probability of being selected and included in the sample (Kothari, 2004). The sample was estimated using Krejcie and Morgan's (1970) formula for sample size calculation.

A structured questionnaire was used as a data-gathering instrument. The questionnaire used in a study conducted by Rashid et al. (2010) was adopted and modified. The items in the questionnaire were formed using a five-point Likert scale (Lois \& Gavin, 2010), consisting of 28 items. The questionnaire was administered to the randomly selected sample of 420 students across the selected secondary schools. The main objective was to gather information about English literature approaches preferred by the students in learning the English literature subjects. In the process of distributing the questionnaire, the students were guided on how to respond to the questions.

\section{Data Analysis}

The data were analyzed using descriptive statistics, consisting of mean, standard deviation, frequency, and percentage (James, 2012).
The six approaches to the teaching of literature were used in the questionnaire. To ensure reliability, a pilot study was conducted using a sample of 30 respondents to determine if the questions would yield the desired information necessary for the study and to avoid inappropriate, misleading, and redundant questions. A Cronbach's Alpha of .922 was obtained, which is within the acceptable range $(0.70-0.95)$ of statistical values (Tavakol \& Dennick, 2011). The descriptive statistics used in this study were calculated using the SPSS statistical software package (SPSS Inc., Chicago, IL, USA, 20.0).

\section{Findings}

As mentioned earlier, 420 questionnaires were administered across the selected secondary schools. Out of this number of questionnaires, 409 were returned, representing a high response rate of 97.4 percent. Besides, six questionnaires were rejected during analysis due to incomplete and invalid responses. Therefore, a total of 403 questionnaires were considered for analysis. Majority $(58.8 \%)$ of the students are females while $41.2 \%$ are males. Besides, majority of the students $(91.8 \%)$ were 16 years of age, $7.2 \%$ were above 16 while only $1.0 \%$ were 15 years old. A sizeable number (97.0\%) of the students are Malays while Chinese, Indians, and other ethnic groups constitute $1.0 \%$ respectively.

In the descriptive statistics, A+SA represents a combination of «Agree» and «Strongly Agree» responses as specified in the questionnaire. It was used to show the frequency of students who agree with the statements provided in the questionnaire. In addition, $\mathrm{D}+\mathrm{SD}$ represents «Disagree» and «Strongly Disagree» which was used to show the frequency of students who disagree with the statements. Similarly, N stands for «Neutral» and was used to show the frequency of students who neither agree nor disagree with the statements. Since the five-point Likert scale suggests that «5»" represents the highest mean value, the values of each construct are reported within the range of 0.00 and 5.00. Table 1 shows the descriptive statistics for the English Literature approaches preferred by the students. 
Table 1. Preferred approaches to the teaching of English Literature

\begin{tabular}{|c|c|c|c|c|c|c|}
\hline \multirow{2}{*}{\multicolumn{2}{|c|}{ Approaches }} & \multirow[b]{2}{*}{ Mean } & \multirow[b]{2}{*}{ SD } & \multicolumn{3}{|c|}{ Total (F/\%) } \\
\hline & & & & $\mathrm{A}+\mathrm{SA}$ & $\mathrm{D}+\mathrm{SD}$ & $\mathrm{N}$ \\
\hline 1 & 2 & 3 & 4 & 5 & 6 & 7 \\
\hline & Information-based approach & & & & & \\
\hline 1 & $\begin{array}{l}\text { Teacher guides students to identify and read informa- } \\
\text { tive extracts in the story }\end{array}$ & 4.03 & .869 & $315(78.2)$ & $20(32.0)$ & $68(16.9)$ \\
\hline 2 & $\begin{array}{l}\text { Teacher provides specific details on the literary ele- } \\
\text { ments found in the text }\end{array}$ & 3.94 & .887 & $196(73.5)$ & $29(7.2)$ & 78(19.4) \\
\hline 3 & Teacher elicits information from students about the text & 3.32 & .922 & $173(42.9)$ & $70(17.4)$ & $160(39.7)$ \\
\hline 4 & $\begin{array}{l}\text { Teacher explains the main content of the text to the } \\
\text { class }\end{array}$ & 4.14 & .847 & $332(82.4)$ & $20(5.0)$ & $47(11.7)$ \\
\hline 5 & $\begin{array}{l}\text { Teacher explains to the students with background in- } \\
\text { formation of the text }\end{array}$ & 4.05 & .915 & $301(74.7)$ & $20(4.9)$ & 76(18.9) \\
\hline & Total & 3.90 & .888 & 70.34 & 13.30 & 21.32 \\
\hline & Paraphra & & & & & \\
\hline 6 & $\begin{array}{l}\text { vides a written paraphrased version of a } \\
\text { tary reading text }\end{array}$ & 3.77 & .925 & $271(67.2)$ & $34(8.5)$ & 98(24.3) \\
\hline 7 & Teacher solely uses a paraphrased version of the text & 2.87 & .950 & $94(23.4)$ & $143(35.5)$ & $165(40.9)$ \\
\hline 8 & Teacher guides students to paraphrase the text & 4.00 & .893 & 297(73.7) & 20(4.9) & $84(20.8)$ \\
\hline 9 & urative and ambiguous language & 3 & 31 & .8) & .8) & 1) \\
\hline 10 & pple terms to explain what the story is & 4.26 & .955 & $334(82.9)$ & $21(5.2)$ & $45(11.2)$ \\
\hline & Total & 3.73 & 1.00 & 62.2 & 14.8 & 22.7 \\
\hline & Styl & & & & & \\
\hline 11 & $\begin{array}{l}\text { Teacher defines the correlation between language and } \\
\text { content of information }\end{array}$ & 3. & 839 & 7.7) & $19(4.5)$ & $0(27.3)$ \\
\hline 12 & $\begin{array}{l}\text { Teacher compares the stylistic effect with other lan- } \\
\text { guages }\end{array}$ & 3.36 & .869 & $163(40.4)$ & $46(11.4)$ & 181(44.9) \\
\hline 13 & $\begin{array}{l}\text { Teacher explains the synonymous units of the words in } \\
\text { the text }\end{array}$ & 3.94 & .939 & $292(72.4)$ & $28(7.0)$ & $82(20.3)$ \\
\hline 14 & Teacher highlights the styles used in the text & 3.80 & .902 & $266(66.0)$ & $32(7.9)$ & $100(24.8)$ \\
\hline 15 & $\begin{array}{l}\text { Teacher asks students to explain the styles used } \\
\text { text }\end{array}$ & 3.36 & 1.037 & $187(46.4)$ & 73(18.2) & 141(35.0) \\
\hline & Total & 3.66 & .917 & 58.6 & 9.80 & 30.46 \\
\hline & Language-based approach & & & & & \\
\hline 16 & Teacher infers meaning from clues in the text & 3.30 & 1.042 & $179(44.5)$ & $82(20.4)$ & $139(34.5$ \\
\hline 17 & Teacher guides students to read between the line & 4.11 & .911 & $315(78.2)$ & $22(5.5)$ & 62(15.4) \\
\hline 18 & $\begin{array}{l}\text { Teacher asks students to make predictions on what will } \\
\text { happen }\end{array}$ & 3.58 & .996 & $224(55.6)$ & $54(13.4)$ & $124(30.8)$ \\
\hline 19 & $\begin{array}{l}\text { Teacher guides students to express opinions towards a } \\
\text { text }\end{array}$ & 3.84 & .922 & $279(69.2)$ & $35(8.6)$ & $87(21.6)$ \\
\hline 20 & $\begin{array}{l}\text { Teacher sets simple language activities in a literature } \\
\text { lesson }\end{array}$ & 3.97 & .941 & 29 & 0) & 74 \\
\hline & Total & 3.76 & 0.962 & 64.2 & 11.0 & 24.1 \\
\hline
\end{tabular}


Continuation of Table 1

\begin{tabular}{|c|c|c|c|c|c|c|}
\hline 1 & 2 & 3 & 4 & 5 & 6 & 7 \\
\hline & Personal-Response approach & & & & & \\
\hline 21 & $\begin{array}{l}\text { Teacher guides students to relate the themes to personal } \\
\text { experiences }\end{array}$ & 3.84 & .922 & $273(67.8)$ & $26(6.4)$ & $100(24.8)$ \\
\hline 22 & $\begin{array}{l}\text { Teacher asks students to compare the text to any text } \\
\text { they have read earlier }\end{array}$ & 3.48 & .939 & 198(49.1) & $54(13.4)$ & $148(36.7)$ \\
\hline 23 & Teacher encourages students to respond to a text & 3.62 & .968 & $217(53.8)$ & $37(9.2)$ & $136(33.7)$ \\
\hline \multirow[t]{3}{*}{24} & $\begin{array}{l}\text { Teacher encourages students to express feelings to- } \\
\text { wards the issues raised in the text }\end{array}$ & 3.65 & 1.02 & $242(60.0)$ & $45(11.1)$ & $114(28.3)$ \\
\hline & Total & 3.65 & .962 & 57.8 & 10.0 & 30.9 \\
\hline & Moral-Philosophical approach & & & & & \\
\hline 25 & Teacher incorporates moral values in the lessons & 4.22 & .859 & $324(80.4)$ & $13(3.2)$ & $65(16.1)$ \\
\hline 26 & $\begin{array}{l}\text { Teacher tells students directly the moral values found } \\
\text { in the text }\end{array}$ & 4.11 & .887 & $320(79.4)$ & $22(5.5)$ & 60(14.9) \\
\hline 27 & $\begin{array}{l}\text { Teacher guides students to search for moral values from } \\
\text { a text }\end{array}$ & 4.03 & .944 & $303(75.2)$ & $22(5.5)$ & 77(19.1) \\
\hline \multirow[t]{2}{*}{28} & $\begin{array}{l}\text { Teacher raises students' awareness of values derived } \\
\text { from the text }\end{array}$ & 4.15 & .961 & $313(77.7)$ & $23(5.7)$ & $66(16.4)$ \\
\hline & Total & 4.13 & .913 & 78.2 & 4.98 & 16.6 \\
\hline
\end{tabular}

Level indicator: Low=0.1-2.99, moderate=3.0-3.49, high=3.5-5.

As shown in Table 1, the most preferred approach amongst the students is the moralphilosophical approach (mean=4.13), followed by the information-based approach and the language-based approach with mean values of 3.90 and 3.76 respectively. Interestingly, these findings agree with Bridget and Omar's (2007) study which focused on popular teaching approaches amongst teachers of English literature. Similarly, Rashid et al. (2010) found the moral-philosophical approach, which represents the most preferred approach amongst students examined in the present study, to be the second most preferred approach amongst literature teachers. Besides, Hwang and Embi (2007) found the moral-philosophical approach to be the third most preferred approach. The findings reported by Rashid et al. (2010) might be different because the study focused on less proficient students. Therefore, the findings of this study are more consistent with Bridget and Omar's (2007) study which revealed that the moral-philosophical approach was the most preferred.
Further analysis of the findings indicates that the statement «Teacher incorporates moral values in the lessons» represents the highest mean value (mean=4.22) which is logically found in the students' responses to the moralphilosophical approach. In this regard, $80.4 \%$ of the students agreed while only $3.2 \%$ did not agree with the statement. According to Kow (2002), cultural perceptions is encouraged by learning of English literature in the Malaysian context. On the other hand, the statement «Teacher solely uses a paraphrased version of the text» represents the lowest mean value (mean=2.87). In this study, students' attitudes, familiarity with the approaches, and their level of language proficiency might influence the selection of their preferred approaches to the teaching of English literature.

\section{Discussion}

In Malaysia, the incorporation of the English literature component into the English language syllabus was introduced since the year 2000 , but the program still attracts interesting discourse amongst researchers, educators, 
and policymakers (Rashid et al., 2010; Hwang \& Embi, 2007). The findings reported in this study showed that the moral-philosophical approach is the most preferred approach amongst the students, followed by the informationbased approach and the language-based approach. This indicates that teachers in the selected secondary schools incorporate moral values in their lessons. The findings of this study are consistent with the study conducted by Bridget and Omar (2007) from the teachers' perspective. Besides, the findings are similar to those obtained in most studies focusing on the literature teaching approaches from teachers' perspective (Hwang \& Embi, 2007; Rashid et al., 2010).

This study shows that the teachers and the students have similar preferences in relation to the literature teaching approaches. When the preferences of students and teachers are consistent, positive learning and teaching outcomes are likely to be achieved (Candlin \& Mercer, 2001; Hwang \& Embi, 2007). By utilizing the moral-philosophical approach, moral values could be inculcated in the students' mindsets. However, the findings show that the personal-response approach, which enables students to interact with the texts (Carter, 1986; Rashid et al., 2010), is the least preferred approach amongst the students. The moral-philosophical approach to teaching English literature is preferred by students, perhaps because they liked their teachers to conduct focus on moral values while teaching the literature subjects.

Through literary texts, students are exposed to the elements of the target culture (Mengu, 2002; Azmi et al., 2020). English literature could be an important means of cultural adaptation and development of moral values which shape the students' personality (Kow, 2002; Mengu, 2002; Ogunnaike, 2002; Tutyrahiza, 2008; Zhen, 2012). According to Tutyrahiza (2008), exposing students to moral values from the text is a valuable strategy regardless of the students' level of language proficiency. The knowledge acquired through the teaching approach also allows students to appreciate the cultural background and morals which could help them in shaping their personality and developing their community (Rahayu, 2009; Velu, 2010; Azmi et al., 2020).

Having integrated the literature component into the EFL syllabus, determining an appropriate approach could be beneficial to the Ministry of Education (Savvidou, 2004; Bridget \& Omar, 2007; Rashid et al., 2010). Therefore, this study offers important clues to the Ministry of Education in relation to the choice of appropriate literature teaching approaches. In turn, this could supplement the effort Curriculum Development Centre toward achieving the best literature learning outcomes. In determining an appropriate teaching approach, students' involvement in the teaching-learning process is paramount and their positive contributions could result in methodological success (Timucin, 2001; Ahmad \& Aziz, 2009).

\section{Conclusion}

This study examined students' preferences for approaches to the teaching of English literature in selected Malaysian secondary schools. According to the findings, the moral-philosophical approach to the teaching of English literature is the most preferred approach amongst the students, followed by the information-based approach and the languagebased approach. In consistence with these findings, research showed that secondary school teachers favor the moral-philosophical approach as well (Bridget \& Omar, 2007). This shows that, certainly, teachers of English literature incorporate moral values in their lessons. The moral-philosophical approach enables students to be aware of moral and philosophical values identifiable through the reading of the literary texts (Rashid et al., 2010).

Since the incorporation of English literature component into the English language syllabus in 2000, research on students' preferences for literature teaching approaches has either been lacking or inadequate. Hence, the findings of this study provide valuable information to the Ministry of Education in relation to the choice of appropriate literature teaching approaches, particularly in the process of curriculum development. Besides, this study could raise teachers' awareness of their students' preferences for 
teaching approaches. To this end, the students are allowed to express their own feelings in regards to the teaching approaches employed by their teachers, which in turn, allows teachers to make decisions in the teaching and learning process. Teachers of English literature are required to encourage their students to develop a passion for reading literary texts.

\section{References}

Ahmad, F., \& Aziz, J. (2009). Students' perception of the teachers' teaching of literature communicating and understanding through the eyes of the audience. In European Journal of Social Sciences, 7(3), $17-26$.

Allen, M., Titsworth, S. \& Hunt, S.K. (2009). Quantitative Research in Communication. London: SAGE Publications.

Amer, A.A. (2003). Teaching EFL/ESL literature. In The Reading Matrix, 3(2). Available at: http://www. readingmatrix.com/articles/amer/article.pdf

Azmi, M. N. L., Hassan, I., Ali, E.M.T.B.E., Hidayah, A.T., Anas, M.B., \& Suhaimi, N.I. (2020b). English Language Learning, Environment, and the Formation of Islamic Self-identity among Students in Selected Religious Secondary Schools. In International Journal of Innovation, Creativity and Change, 11(7), 466-482.

Azmi, M.N.L., Hassan, I., \& Sidek, H.M. (2020). Analysing Trauma in Poems: A Critical Thinking Perspective. Terengganu: UniSZA Press.

Bridget, L.S.H., \& Omar, S. (2007). Approaches adopted in the teaching of poetry for the upper secondary school students in Tawau town area. In The Second Biennial International Conference on Teaching and Learning of English in Asia: Exploring New Frontiers (TELiA2), 341-544. ledge.

Candlin, C \& Mercer, N. (2001). English Language Teaching in Its Social Context. New York: Rout-

Carter, R. (1986). Linguistic models, language and literariness: Study strategies in the teaching of literature to foreign students. In Brumfit, C.J. and Carter, R. (eds.). In Literature and language teaching. Oxford: Oxford University Press, 110-132.

Carter, R. and Long, M. (1991). Teaching literature. Harlow: Longman.

Cheng, K.K. (2016). Issues in the Teaching and Learning of Children's Literature in Malaysia. In Issues in The Teaching and Learning of Children, 9 (2),1-14.

Creswell, J.W. (2012). Research Design: Qualitative, Quantitative and Mixed Method Approaches (2nded.). London: SAGE publications.

Divsar, H., \& Tahriri, A. (2009). Investigating the Effectiveness of an Integrated Approach to Teaching Literature in an EFL Context. In Journal of Pan-Pacific Association of Applied Linguistics, 13(2), $105-116$.

Ghazali, S.N., Setia, R., Muthusamy, C., \& Jusoff, K. (2009). ESL Students' Attitude towards Texts and Teaching Methods Used in Literature Classes. In English language teaching, 2(4), 51-56.

Gopala, K.S., Roszainora, S., Siti Norliana, G., Elangkeeran, S., Razita, M., Mohamad, M.A., \& Che, N.S.I. (2012). Can literature improve English proficiency? The students' perspective. In Asian Social Science, 2 (12), 47-89. DOI:10.5539/ass.v8n12p21

Hişmanoğlu, M. (2005). Teaching English through literature. In Journal of Language and Linguistic Studies, 1(1), 53-66.

Hofler, D.B. (2010). Approach, method, technique a clarification. In Taylor \& Francis Online, 23(1), 71-72. doi: 10.1080/19388078309557742

Hwang, D., \& Embi, M.A. (2007). Approaches employed by secondary school teachers to teaching the literature component in English. In Malaysian Journal of Educators and Education, 22, 1-23.

Ihejirika, R.C. (2014). Literature and English language teaching and learning: A symbiotic relationship. In English Language Teaching, 7(3), 85-90.

James, A.A. (2012). Media Research Method: Understanding Metric and Interpretive Approaches (1sted.). London: SAGE Publication. 
Keshavarzi, A. (2012). Use of literature in teaching English. In Procedia-social and behavioral sciences, 46, 554-559.

Khatib, M., Derakhshan, A., \& Rezaei, S. (2011a). Why \& Why Not Literature: A Task-based approach to teaching literature. In International Journal of English Linguistics, 1(1), 213.

Khatib, M., Rezaei, S., \& Derakhshan, A. (2011b). Literature in EFL/ESL Classroom. In English Language Teaching, 4(1), 201-208.

Kothari, C.R. (2004). Research Methodology Method and Techniques (2nd ed). New Delhi: New Age International.

Kow, Y.C. (2002). Literacy and pre-school children: story-telling strategies. Malaysia: Sasbadi.

Krejcie, R.V., Morgan, D.W. (1970). Determining Sample Size for Research Activities. In Educational and Psychological Measurement, 1(30): 607-610.

Krishnasamy, J. (2015). An Investigation of Teachers' Approaches Employed in Teaching the English Literature. In Asian Journal of Education and e-Learning (ISSN: 2321-2454), 2(3), 136-145.

Lazar, G. (1993). Literature and language teaching: A guide for teachers and trainers. Cambridge: Cambridge University Press.

Lois, H.R., and Gavin, T.L.B. (2010). Mixing interview and questionnaire methods: Practical problems in aligning data. In Practical Assessment, Research and Evaluation, 15 (1). Available at: https://scholarworks.umass.edu/cgi/viewcontent.cgi?article=1227\&context=pare

Mahzan, M.S.W., Alias, N.A., \& Ismail, I.S. (2020). Investigating the needs of developing a digital vocabulary learning material for Malaysian indigenous learners in ESL Classroom. In Journal of Nusantara Studies (JONUS), 5(2), 282-302. DOI:10.24200/jonus.vol5iss2pp282-302

Mengu, H.I. (2002). A Suggested Syllabus for the Drama Teaching Course in ELT Departments (Master's thesis), Hacettepe University, Turkey.

Mustakim, S.S., Mustapha, R., \& Lebar, O. (2014). Teacher's Approaches in Teaching Literature: Observations of ESL Classroom. In Malaysian Online Journal of Educational Sciences, 2(4), $35-44$.

Ogunnaike, J. (2002). Challenges of the teaching and learning of Literature in Nigerian Secondary Schools. In I. Lawal, \& Ohia (Eds.) Perspectives on Applied Linguistics in Language and Literature. Lagos: Stirling-Horden Publishers.

Paran, A. (2008). The role of literature in instructed second language learning and teaching: An evidence-based survey. In Language teaching, 41(4), 465-496.

Rahayu, M. (2009). Literature in language teaching. Jurnal Ilmu Bahasa dan Sastra, 4(1). Available at: http://103.17.76.13/index.php/humbud/article/view/591/978

Rashid, R.A., Vethamani, M.E., \& Rahman, S.B.A. (2010). Approaches employed by teachers in teaching Literature to less proficient students in Form 1 and Form 2. In English Language Teaching, 3(4), 87-99.

Savvidou, C. (2004). An integrated approach to teaching literature in the EFL classroom. In The Internet TESL Journal, 10(12), 1-6.

Simpson, P. (2003). Language through literature: An introduction. Routledge.

Subramaniam, G. (2007). Literature programme in Malaysian schools: then and now. In Teaching English in Malaysia, 1(1), 50-62.

Tavakol, M., \& Dennick, R. (2011). Post-examination analysis of objective tests. Medical Teacher, 33(6), 447-458. DOI: 10.3109/0142159X.2011.564682

Timucin, M.E.T.I.N. (2001). Gaining insight into alternative teaching approaches employed in an EFL literature class. In Revista de Filología y su Didáctica, 24, 269-293.

Tina, A., Mohammad, H.Z., Fauziah, I., Fara, A. \& Marzilah, A.Z. (2007). A New Teaching Model to Teach Literature for the Tesl Pre-Training Service Programme in Universiti Teknologi Malaysia. Available at: http://eprints.utm.my/id/eprint/3970/1/75167.pdf

Tutyrahiza, M. (2008). Teaching Reading Strategies Used by ESL Teachers that Facilitate Teaching and Learning Reading (Master's Thesis). University Malaysia Sarawak, Malaysia. 
Van, T.T.M. (2009). The relevance of literary analysis to teaching literature in the EFL Classroom. In English Teaching Forum (47 (3), 2). US Department of State. Bureau of Educational and Cultural Affairs, Office of English Language Programs, SA-5, 2200 C Street NW 4th Floor, Washington, DC20037.

Velu, J. (2010). Psychometric analysis of lecturers' self-efficacy instrument. In HERDSA Annual International, 2(3), 65-96.

Whitehead, R. (1968). Children's literature: Strategies of teaching. Englewood Cliffs, NJ: PrenticeHall Inc.

Zhen, Z. (2012). Characteristics and strategies of literature teaching in the EFL context in China. In International Journal of Electronics and Communication Engineering, 5 (3), 35-43. 